\title{
Is Stimulated Thyroglobulin Necessary after Ablation in All Patients with Papillary Thyroid Carcinoma and Basal Thyroglobulin Detectable by a Second-Generation Assay?
}

\author{
Pedro Weslley Rosario, ${ }^{1,2}$ Gabriela Franco Mourão, ${ }^{1,2}$ and Maria Regina Calsolari ${ }^{2}$ \\ ${ }^{1}$ Postgraduate Program, Santa Casa de Belo Horizonte, 590 Domingos Vieira Street, 30150340 Belo Horizonte, MG, Brazil \\ ${ }^{2}$ Endocrinology Service, Santa Casa de Belo Horizonte, 1111 Francisco Sales Avenue, 30150221 Belo Horizonte, MG, Brazil \\ Correspondence should be addressed to Pedro Weslley Rosario; pedrowsrosario@gmail.com
}

Received 26 May 2015; Accepted 3 August 2015

Academic Editor: Thomas J. Fahey

Copyright ( $\odot 2015$ Pedro Weslley Rosario et al. This is an open access article distributed under the Creative Commons Attribution License, which permits unrestricted use, distribution, and reproduction in any medium, provided the original work is properly cited.

\begin{abstract}
Objective. To evaluate the percentage of elevated stimulated thyroglobulin (sTg) and persistent or recurrent disease (PRD) in patients with detectable basal $\mathrm{Tg}<0.3 \mathrm{ng} / \mathrm{mL}$. Methods. The sample consisted of 130 patients with papillary thyroid carcinoma (PTC) who were at low risk of PRD and who had neck ultrasound (US) without abnormalities, negative anti-Tg antibodies (TgAb), and detectable basal $\mathrm{Tg}<0.3 \mathrm{ng} / \mathrm{mL}$ about 6 months after ablation. Results. sTg was $<1 \mathrm{ng} / \mathrm{mL}$ in 88 patients (67.7\%), between 1 and $2 \mathrm{ng} / \mathrm{mL}$ in $26(20 \%)$, and $\geq 2 \mathrm{ng} / \mathrm{mL}$ in $16(12.3 \%)$. Imaging methods revealed the absence of tumors in 16 patients with elevated sTg. During follow-up, Tg increased to $0.58 \mathrm{ng} / \mathrm{mL}$ in one patient and lymph node metastases were detected. Sixty-nine patients continued to have detectable $\mathrm{Tg}<0.3 \mathrm{ng} / \mathrm{mL}$ and US revealed recurrence in only one patient. Sixty patients progressed to persistently undetectable Tg without apparent disease on US. Conclusions. In low-risk patients with PTC who have detectable basal $\mathrm{Tg}<0.3 \mathrm{ng} / \mathrm{mL}$ after ablation, negative TgAb, and US, persistent disease is rare and eventual recurrences can be detected by basal Tg elevation and/or subsequent US assessments, with follow-up without sTg being an "alternative" to Tg stimulation.
\end{abstract}

\section{Introduction}

Stimulated thyroglobulin (sTg) is not recommended for the follow-up of patients with papillary thyroid carcinoma (PTC) submitted only to thyroidectomy (without radioiodine). In patients treated with ${ }^{131} \mathrm{I}$, sTg is not necessary if basal Tg is significantly elevated (traditionally $>1 \mathrm{ng} / \mathrm{mL}$ ) or, at the other extreme, in patients with the following criteria: (i) apparently complete tumor resection, (ii) absence of uptake outside the thyroid bed on posttherapy whole-body scanning (RxWBS), (iii) low risk of persistent or recurrent disease (PRD), (iv) neck ultrasound (US) showing no tumor, (v) absence of interference of anti-Tg antibodies (TgAb), and (vi) basal $\mathrm{Tg}$ "undetectable" by a second-generation assay (functional sensitivity of approximately $0.1 \mathrm{ng} / \mathrm{mL}$ ). The need for sTg is controversial in patients who meet criteria (i) to (v) but have slightly elevated basal Tg measured with a second-generation assay. The European Society for Medical Oncology [1], the Brazilian Society of Endocrinology and Metabolism [2], the British Thyroid Association [3], and a recent European consensus [4] recommend sTg not to be necessary only when basal Tg is really "undetectable." However, others extend this recommendation to patients with detectable $\mathrm{Tg}<0.25-$ $0.3 \mathrm{ng} / \mathrm{mL}$ [5-7]. Some information is important to define the need for sTg in these cases: (a) percentage of patients with elevated sTg, (b) rate of persistent disease (not detected by US), and (c) rate of tumor recurrence after initial assessment.

The present study evaluated patients with PTC who met criteria (i) to (v) described above and had detectable basal $\mathrm{Tg}<0.3 \mathrm{ng} / \mathrm{mL}$ about 6 months after ablation with ${ }^{131} \mathrm{I}$. The objectives were to determine the percentage of patients with elevated sTg, persistent disease on initial assessment, and recurrence during follow-up.

\section{Materials and Methods}

2.1. Patients. First, patients seen at our institution between December 2006 (when the second-generation Tg assay 
started to be used) and January 2013 (limit defined to have a minimum follow-up of 2 years) who met the following criteria were selected: (a) diagnosis of PTC, (b) submitting to total thyroidectomy followed by ablation with ${ }^{131} \mathrm{I}$, with apparently complete tumor resection and RxWBS showing no uptake outside the thyroid bed, (c) low risk of PRD (according to the British Thyroid Association [3] and American Thyroid Association [8]), and (d) US without abnormalities, negative $\mathrm{TgAb}$, and detectable basal $\mathrm{Tg}<0.3 \mathrm{ng} / \mathrm{mL}$ about 6 months after initial therapy [5-7]. Patients with classical papillary microcarcinoma restricted to the thyroid and the noninvasive encapsulated follicular variant of PTC $[3,9]$ (no indication for ablation) were excluded.

2.2. Protocol. During initial assessment, sTg (with or without diagnostic WBS (DxWBS)) was obtained in all patients. In patients with $s T g \geq 2 \mathrm{ng} / \mathrm{mL}[1,3,10-16]$, other imaging methods were performed [chest and mediastinal computed tomography (CT), ${ }^{99 m}$ Tc-MIBI scans, and fluorodeoxyglucose positron emission tomography (FDG-PET)/CT]. In the case of patients without apparent disease on initial assessment, $\mathrm{Tg}$ and $\mathrm{TgAb}$ were measured at intervals of 6 months and US was performed annually or when Tg was increased. After 2 years, a new sTg measurement was obtained in patients in whom $\mathrm{Tg}$ continued to be detectable and whose initial sTg was $\geq 2 \mathrm{ng} / \mathrm{mL}$. Other imaging methods [chest CT and FDG-PET/CT] were repeated when the second $\mathrm{sTg}$ continued to be $\geq 2 \mathrm{ng} / \mathrm{mL}[1,3,10-16]$. TSH was maintained between 0.3 and $2 \mathrm{mIU} / \mathrm{L}$. The time of follow-up ranged from 24 to 96 months (median 60 months).

The study was approved by the research ethics committee of our institution.

2.3. $\mathrm{Tg}$ and $\mathrm{TgAb}$ Measurement. Tg was measured using a chemiluminescent assay (Access Thyroglobulin Assay, Beckman Coulter, Fullerton, CA). In our laboratory, the interassay imprecision profile assessed within 8 months using 10 different serum pools indicated $26 \%$ variability at $0.05 \mathrm{ng} / \mathrm{mL}$, $17 \%$ at $0.12 \mathrm{ng} / \mathrm{mL}, 15 \%$ at $0.15 \mathrm{ng} / \mathrm{mL}, 13 \%$ at $0.25 \mathrm{ng} / \mathrm{mL}, 10 \%$ at $0.52 \mathrm{ng} / \mathrm{mL}, 9 \%$ at $0.9 \mathrm{ng} / \mathrm{mL}, 2.1 \mathrm{ng} / \mathrm{mL}, 7 \%$ at $4.2 \mathrm{ng} / \mathrm{mL}$, and $5 \%$ at 7.1 and $10.8 \mathrm{ng} / \mathrm{mL}$ (functional sensitivity of $0.1 \mathrm{ng} / \mathrm{mL}$ (20\% variability)). TgAb were measured using a chemiluminescent assay (IMMULITE 2000, Diagnostic Products Corporation, Los Angeles, CA (reference value of up to $40 \mathrm{IU} / \mathrm{mL}$ ) or Architect Anti-Tg (Abbott Laboratories, IL; reference value of up to $4.11 \mathrm{IU} / \mathrm{mL})$ ).

2.4. Imaging Methods. WBS was performed with a tracer $(185 \mathrm{MBq})$ or therapeutic $(1.1$ or $3.7 \mathrm{GBq})$ activity of ${ }^{131} \mathrm{I}$ and a low-iodine diet during the 10 days preceding iodine administration. Anterior and posterior whole-body images were obtained 3 (DxWBS) or 7 (RxWBS) days after iodine administration. US was performed with a linear multifrequency transducer for morphological analysis (B-mode) and for power Doppler evaluation. All suspected lesions apparent on US scans $[18,19]$ were evaluated by US-guided fine needle aspiration biopsy. Chest and mediastinal CT was performed on $5 \mathrm{~mm}$ thick sequential sections. ${ }^{99 \mathrm{~m}}$ Tc-MIBI scans were
TABLE 1: Characteristics of the patients studied.

\begin{tabular}{|c|c|}
\hline Characteristic & Result \\
\hline \multirow{2}{*}{ Gender } & 115 women $(88.4 \%)$ \\
\hline & 15 men $(11.6 \%)$ \\
\hline Age (years) & 18 to 78 (median 48 ) \\
\hline \multicolumn{2}{|l|}{ Tumor } \\
\hline \multirow{2}{*}{ Histological subtype } & Classical: 105 (80.7\%) \\
\hline & Follicular variant: 25 (19.2\%) \\
\hline Multicentricity & $45(34.6 \%)$ \\
\hline \multirow{3}{*}{ Size $(\mathrm{TNM})^{\mathrm{a}}$} & $\leq 2 \mathrm{~cm}(\mathrm{pT} 1 \mathrm{bNxM} 0): 45(34.6 \%)$ \\
\hline & $2-4 \mathrm{~cm}(\mathrm{pT} 2 \mathrm{NxM} 0): 65(50 \%)$ \\
\hline & $>4 \mathrm{~cm}$ (pT3NxM0): 20 (15.4\%) \\
\hline $\begin{array}{l}\text { Age }>45 \text { years or tumor }>2 \mathrm{~cm} \\
\text { or multicentric }\end{array}$ & $118(90.7 \%)$ \\
\hline \multirow{3}{*}{ Stage [17] } & I: $83(63.8 \%)$ \\
\hline & II: $36(27.7 \%)$ \\
\hline & III: $11(8.5 \%)$ \\
\hline \multirow{2}{*}{${ }^{131}$ I activity } & 1.1 GBq: 68 (52.3\%) \\
\hline & 3.7 GBq: $62(47.7 \%)$ \\
\hline
\end{tabular}

${ }^{a}$ Elective dissection of lymph nodes of the central compartment was not performed; thus, all patients were $\mathrm{cNO} \mathrm{pNx}$.

performed during levothyroxine therapy using a tracer dose of $720-925 \mathrm{MBq}$, and whole-body images were obtained during the early (20 minutes) and late period (6 hours). FDG-PET was carried out after stimulation with recombinant human TSH.

The diagnosis of a tumor in lesions detected by the imaging methods was made by cytology or histology and/or based on unequivocal ectopic uptake (excluding false-positive results) on DxWBS/RxWBS or FDG-PET/CT.

\section{Results}

3.1. Patients. The characteristics of the patients are shown in Table 1. According to the British Thyroid Association [3] and American Thyroid Association [8], all patients were at low risk (selection criterion).

3.2. Basal Tg. Basal $\mathrm{Tg}$ ranged from 0.12 to $0.29 \mathrm{ng} / \mathrm{mL}$ (median $0.21 \mathrm{ng} / \mathrm{mL}$ ). TSH concentrations ranged from 0.16 to $2.4 \mathrm{mIU} / \mathrm{L}$ (median $1.2 \mathrm{mIU} / \mathrm{L}$ ) at the time of basal $\mathrm{Tg}$ measurement.

3.3. Stimulated $\mathrm{Tg}$. Stimulated $\mathrm{Tg}$ was $<1 \mathrm{ng} / \mathrm{mL}$ in 88 patients (67.7\%), between 1 and $2 \mathrm{ng} / \mathrm{mL}$ in $26(20 \%)$, and $\geq 2 \mathrm{ng} / \mathrm{mL}$ in $16(12.3 \%)$, ranging from 2.1 to $4.86 \mathrm{ng} / \mathrm{mL}$ in the latter. DxWBS was available for 60 patients with sTg < $2 \mathrm{ng} / \mathrm{mL}$ and for 9 patients with $\mathrm{sTg} \geq 2 \mathrm{ng} / \mathrm{mL}$ and showed only discrete uptake in the thyroid bed in 9 and 5 patients, respectively. The other imaging methods (chest CT, ${ }^{99} \mathrm{~m}$ TcMIBI scans, and FDG-PET/CT) also detected no tumors in the 16 patients with $s \mathrm{Tg} \geq 2 \mathrm{ng} / \mathrm{mL}$. 


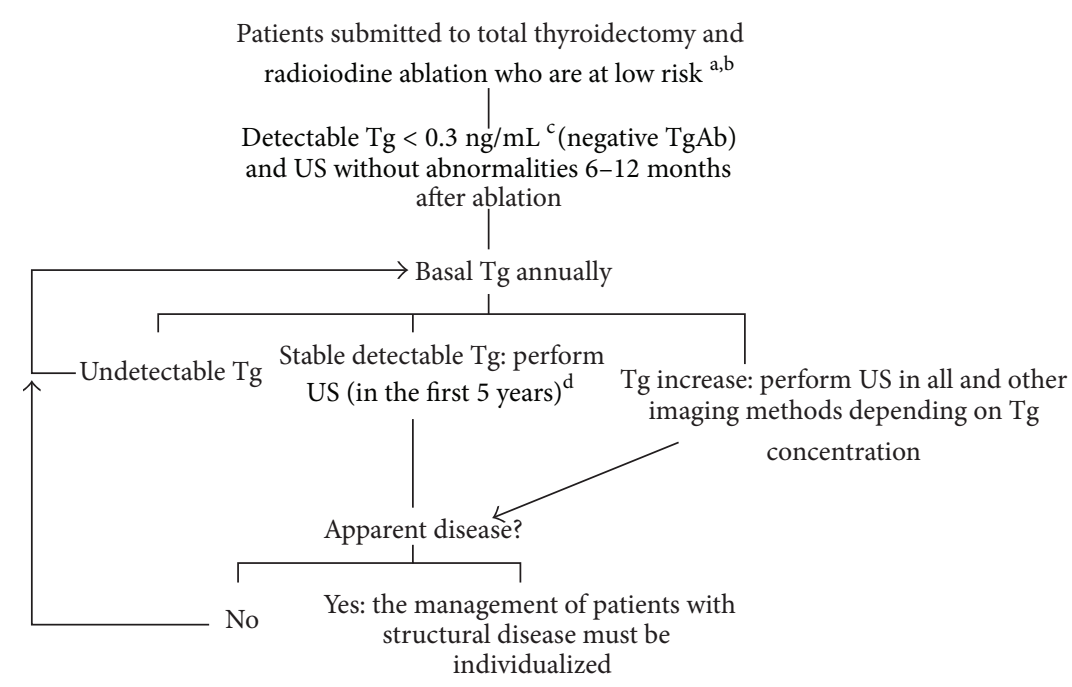

FIGURE 1: Follow-up proposal for low-risk patients with detectable $\mathrm{Tg}<0.3 \mathrm{ng} / \mathrm{mL}$, negative circulating TgAb, and negative US after ablation. $\mathrm{Tg}$, thyroglobulin; TgAb, anti-thyroglobulin antibodies; US, neck ultrasound. ${ }^{a}$ The algorithm does not apply to patients not submitted to ablation. ${ }^{\mathrm{b}}$ Low risk defined according to currently recommended classifications $[3,8] .{ }^{\mathrm{c}}$ Considering a second-generation assay with a functional sensitivity of $0.1 \mathrm{ng} / \mathrm{mL}$. ${ }^{\mathrm{d}}$ After 5 years of stable detectable Tg and negative US, follow-up can be performed exclusively by annual measurement of basal Tg and imaging methods are only needed in the case of an increase.

3.4. Follow-Up after Initial Assessment. Tg increased to $0.58 \mathrm{ng} / \mathrm{mL}$ in one patient and lymph node metastases were detected.

Sixty-nine patients continued to have detectable $\mathrm{Tg}<$ $0.3 \mathrm{ng} / \mathrm{mL}$. US detected neck recurrence in only one case (with $\operatorname{Tg} 0.15 \mathrm{ng} / \mathrm{mL}$ ). Among the 68 patients with detectable $\mathrm{Tg}$ and negative US, sTg was repeated in 11 patients with initial $\mathrm{sTg} \geq 2 \mathrm{ng} / \mathrm{mL}$ and was $<2 \mathrm{ng} / \mathrm{mL}$ in 4 and remained $\geq 2 \mathrm{ng} / \mathrm{mL}$ and stable in 7 . In the latter cases, chest CT and FDG-PET/CT continued to show no disease.

Sixty patients progressed to persistently undetectable basal $\mathrm{Tg}$ in the absence of any additional therapy and apparent disease on US.

3.5. Initial sTg and Recurrence. Recurrence was observed in $0 / 88$ patients with initial $\mathrm{sTg}<1 \mathrm{ng} / \mathrm{mL}$, in $1 / 26$ patients with initial $\mathrm{sTg}$ between 1 and $2 \mathrm{ng} / \mathrm{mL}$, and in $1 / 16$ patients with initial sTg $\geq 2 \mathrm{ng} / \mathrm{mL}$.

\section{Discussion}

Since this study was aimed at and included only lowrisk patients $[3,8]$, in principle, its results are limited to these subjects. Measurement of sTg is not necessary for the follow-up of low-risk patients with PTC submitted only to thyroidectomy (without radioiodine), who have significantly elevated basal $\mathrm{Tg}$ after ablation (traditionally $>1 \mathrm{ng} / \mathrm{mL}$ ) or, at the other extreme, who exhibit undetectable basal Tg measured with a second-generation assay. Stimulated Tg testing remains recommended for patients with basal $\mathrm{Tg}<$ $1 \mathrm{ng} / \mathrm{mL}$ but higher than $0.25-0.3 \mathrm{ng} / \mathrm{mL}$ after ablation [5-7]. Hence, the patients evaluated in the present study (detectable basal $\mathrm{Tg}<0.3 \mathrm{ng} / \mathrm{mL}$ ) exactly represent the group for which controversy regarding the use of sTg exists [1-7]. Since US should be performed routinely after initial therapy, the lack of detection of tumors by this imaging method was also an inclusion criterion.

The focus of previous studies using the same $\mathrm{Tg}$ assay was patients with undetectable $\mathrm{Tg}$ and there were none $[20,21]$ or only few $[12,22-24]$ individuals with Tg slightly elevated. In the largest series [5], patients with undetectable and detectable $\mathrm{Tg} \leq 0.27 \mathrm{ng} / \mathrm{mL}$ were analyzed together, a fact that may have underestimated the frequency of elevated sTg and PRD, specifically in the latter.

In the present study, none of the patients had persistent disease (i.e., detected during initial assessment). In previous series, US detected most cases of persistent disease among patients with detectable $\mathrm{Tg} \leq 0.3 \mathrm{ng} / \mathrm{mL}[5,12,22-24]$ and the cases not detected by US (except for one) were patients at high or intermediate risk $[12,24]$. These findings agree with our result; that is, persistent disease is rare in low-risk patients with detectable $\mathrm{Tg}<0.3 \mathrm{ng} / \mathrm{mL}$ and without US abnormalities. Recurrences (i.e., tumors detected subsequently during follow-up) were only observed in two of our patients (1.5\%). Although the time of follow-up was a limitation of our study, its duration was at least 2 years (median 5 years) and it is known that $3 / 4$ of recurrences occur during these first years $[5,25,26]$. Furthermore, basal $\mathrm{Tg}$ measured in the last assessment was undetectable in more than half of the patients and remained stable at $<0.3 \mathrm{ng} / \mathrm{mL}$ in the remaining ones. Stimulated Tg obtained after ablation or repeated at the end of the study was $<2 \mathrm{ng} / \mathrm{mL}[1,3,10-16]$ in $90 \%$ of the patients. These findings make the long-term occurrence of a relevant number of additional recurrences unlikely. Consistently, in previous studies recurrences in patients with detectable initial $\mathrm{Tg} \leq 0.3 \mathrm{ng} / \mathrm{mL}$ only occurred in high- or intermediate-risk patients $[5,24]$. As in the present study, 
these (late) recurrences are suspected by basal Tg elevation or US in subsequent assessments.

\section{Conclusions}

We conclude that in low-risk patients with PTC $[3,8]$, who have detectable basal $\mathrm{Tg}<0.3 \mathrm{ng} / \mathrm{mL}$ after ablation [5-7] measured with a second-generation assay (functional sensitivity of $0.1 \mathrm{ng} / \mathrm{mL}$ ), negative circulating TgAb, and negative US, persistent disease is rare and eventual recurrences can be detected by basal $\mathrm{Tg}$ elevation and/or subsequent US assessments, with the follow-up without stimulated Tg proposed in Figure 1 being an "alternative" to Tg stimulation.

\section{Conflict of Interests}

The authors declare no potential conflict of interests.

\section{References}

[1] F. Pacini, M. G. Castagna, L. Brilli, and G. Pentheroudakis, "Thyroid cancer: ESMO clinical practice guidelines for diagnosis, treatment and follow-up," Annals of Oncology, vol. 23, supplement 7, Article ID mds230, pp. viil10-vii119, 2012.

[2] P. W. Rosário, L. S. Ward, G. A. Carvalho et al., "Thyroid nodules and differentiated thyroid cancer: update on the Brazilian consensus," Brazilian Archives of Endocrinology and Metabolism, vol. 57, no. 4, pp. 240-264, 2013.

[3] P. Perros, K. Boelaert, S. Colley et al., "Guidelines for the management of thyroid cancer," Clinical Endocrinology, vol. 81, supplement 1, pp. 1-122, 2014.

[4] L. Giovanella, P. M. Clark, L. Chiovato et al., "Diagnosis of endocrine disease: Thyroglobulin measurement using highly sensitive assays in patients with differentiated thyroid cancer: a clinical position paper," European Journal of Endocrinology, vol. 171, no. 2, pp. R33-R46, 2014.

[5] M. Brassard, I. Borget, A. Edet-Sanson et al., "Long-term follow-up of patients with papillary and follicular thyroid cancer: a prospective study on 715 patients," Journal of Clinical Endocrinology and Metabolism, vol. 96, no. 5, pp. 1352-1359, 2011.

[6] M. Schlumberger, I. Borget, C. Nascimento, M. Brassard, and S. Leboulleux, "Treatment and follow-up of low-risk patients with thyroid cancer," Nature Reviews Endocrinology, vol. 7, no. 10, pp. 625-628, 2011.

[7] S. I. Sherman, "The role of recombinant human thyrotropin for diagnostic monitoring of patients with differentiated thyroid cancer," Endocrine Practice, vol. 19, no. 1, pp. 157-161, 2013.

[8] D. S. Cooper, G. M. Doherty, B. R. Haugen et al., "Revised American thyroid association management guidelines for patients with thyroid nodules and differentiated thyroid cancer," Thyroid, vol. 19, no. 11, pp. 1167-1214, 2009.

[9] P. W. Rosario, G. C. Penna, and M. R. Calsolari, "Noninvasive encapsulated follicular variant of papillary thyroid carcinoma: is lobectomy sufficient for tumours $\geq 1 \mathrm{~cm}$ ?" Clinical Endocrinology, vol. 81, no. 4, pp. 630-632, 2014.

[10] E. L. Mazzaferri, R. J. Robbins, C. A. Spencer et al., "A consensus report of the role of serum thyroglobulin as a monitoring method for low-risk patients with papillary thyroid carcinoma," The Journal of Clinical Endocrinology \& Metabolism, vol. 88, no. 4, pp. 1433-1441, 2003.
[11] F. Pacini, M. Schlumberger, H. Dralle et al., "European consensus for the management of patients with differentiated thyroid carcinoma of the follicular epithelium," European Journal of Endocrinology, vol. 154, pp. 787-803, 2006.

[12] A. Iervasi, G. Iervasi, M. Ferdeghini et al., "Clinical relevance of highly sensitive Tg assay in monitoring patients treated for differentiated thyroid cancer," Clinical Endocrinology, vol. 67, no. 3, pp. 434-441, 2007.

[13] F. Pitoia, L. Ward, N. Wohllk et al., "Recommendations of the Latin American Thyroid Society on diagnosis and management of differentiated thyroid cancer," Brazilian Archives of Endocrinology and Metabolism, vol. 53, no. 7, pp. 884-897, 2009.

[14] NCCN, National Comprehensive Cancer Network Clinical Practice Guidelines in Oncology. Thyroid Carcinoma Version 1, 2015, http://www.nccn.org.

[15] R. Michael Tuttle, Differentiated thyroid cancer: overview of management, http://www.uptodate.com.

[16] G. Francis, S. G. Waguespack, A. J. Bauer et al., "Management guidelines for children with thyroid nodules and differentiated thyroid cancer: The American Thyroid Association Guidelines Task Force on Pediatric Thyroid Cancer," Thyroid, vol. 25, no. 7, pp. 716-759, 2015.

[17] S. B. Edge, D. R. Byrd, C. C. Compton et al., Eds., AJCC Cancer Staging Manual, Springer, New York, NY, USA, 7th edition, 2010.

[18] P. W. Souza Rosário, S. de Faria, L. Bicalho et al., "Ultrasonographic differentiation between metastatic and benign lymph nodes in patients with papillary thyroid carcinoma," Journal of Ultrasound in Medicine, vol. 24, no. 10, pp. 1385-1389, 2005.

[19] P. W. Rosário, W. C. Tavares, M. A. R. Borges, J. B. N. Santos, and M. R. Calsolari, "Ultrasonographic differentiation of cervical lymph nodes in patients with papillary thyroid carcinoma after thyroidectomy and radioiodine ablation: a prospective study," Endocrine Practice, vol. 20, no. 4, pp. 293-298, 2014.

[20] A. M. Chindris, N. N. Diehl, J. E. Crook, V. Fatourechi, and R. C. Smallridge, "Undetectable sensitive serum thyroglobulin $(<\mathrm{ng} / \mathrm{ml})$ in 163 patients with follicular cell-derived thyroid cancer: results of rhTSH stimulation and neck ultrasonography and long-term biochemical and clinical follow-up," Journal of Clinical Endocrinology and Metabolism, vol. 97, no. 8, pp. 27142723, 2012.

[21] P. W. S. Rosario, J. B. N. Dos Santos, and M. R. Calsolari, "Follow-up of patients with low-risk papillary thyroid carcinoma and undetectable basal serum thyroglobulin after ablation measured with a sensitive assay: a prospective study," Hormone and Metabolic Research, vol. 45, no. 12, pp. 911-914, 2013.

[22] P. W. Rosario and S. Purisch, "Does a highly sensitive thyroglobulin $(\mathrm{Tg})$ assay change the clinical management of lowrisk patients with thyroid cancer with $\mathrm{Tg}$ on $\mathrm{T} 4<1 \mathrm{ng} / \mathrm{ml}$ determined by traditional assays?" Clinical Endocrinology, vol. 68, no. 3, pp. 338-342, 2008.

[23] M. G. Castagna, H. P. Tala Jury, C. Cipri et al., "The use of ultrasensitive thyroglobulin assays reduces but not abolishes the need for TSH stimulation in patients with differentiated thyroid carcinoma," Journal of Endocrinological Investigation, vol. 34, pp. 219-223, 2011.

[24] C. C. Nakabashi, T. S. Kasamatsu, F. Crispim et al., "Basal serum thyroglobulin measured by a second-generation assay is equivalent to stimulated thyroglobulin in identifying metastases in patients with differentiated thyroid cancer with low or 
intermediate risk of recurrence," European Thyroid Journal, vol. 3, pp. 43-50, 2014.

[25] G. K. Won, H. Y. Jong, B. K. Won et al., "Change of serum antithyroglobulin antibody levels is useful for prediction of clinical recurrence in thyroglobulin-negative patients with differentiated thyroid carcinoma," The Journal of Clinical Endocrinology \& Metabolism, vol. 93, no. 12, pp. 4683-4689, 2008.

[26] C. Durante, T. Montesano, M. Torlontano et al., "Papillary thyroid cancer: time course of recurrences during postsurgery surveillance," The Journal of Clinical Endocrinology \& Metabolism, vol. 98, no. 2, pp. 636-642, 2013. 


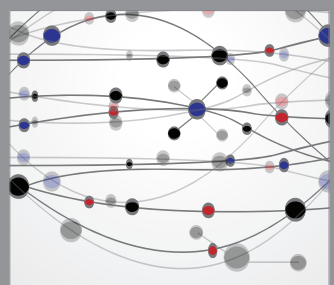

The Scientific World Journal
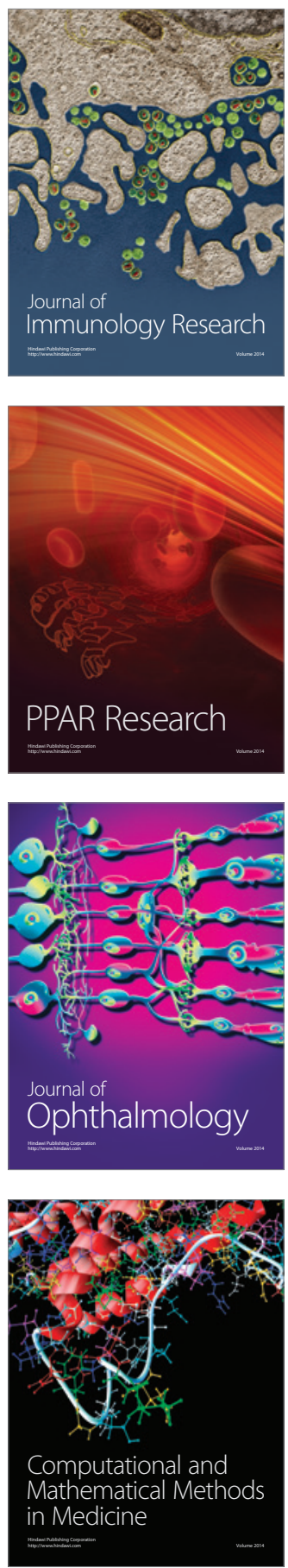

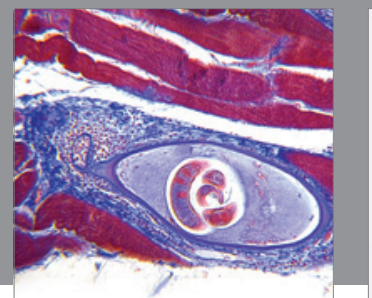

Gastroenterology

Research and Practice
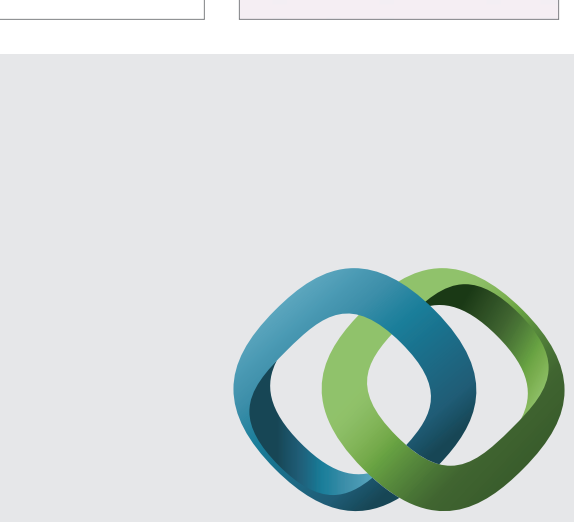

\section{Hindawi}

Submit your manuscripts at

http://www.hindawi.com
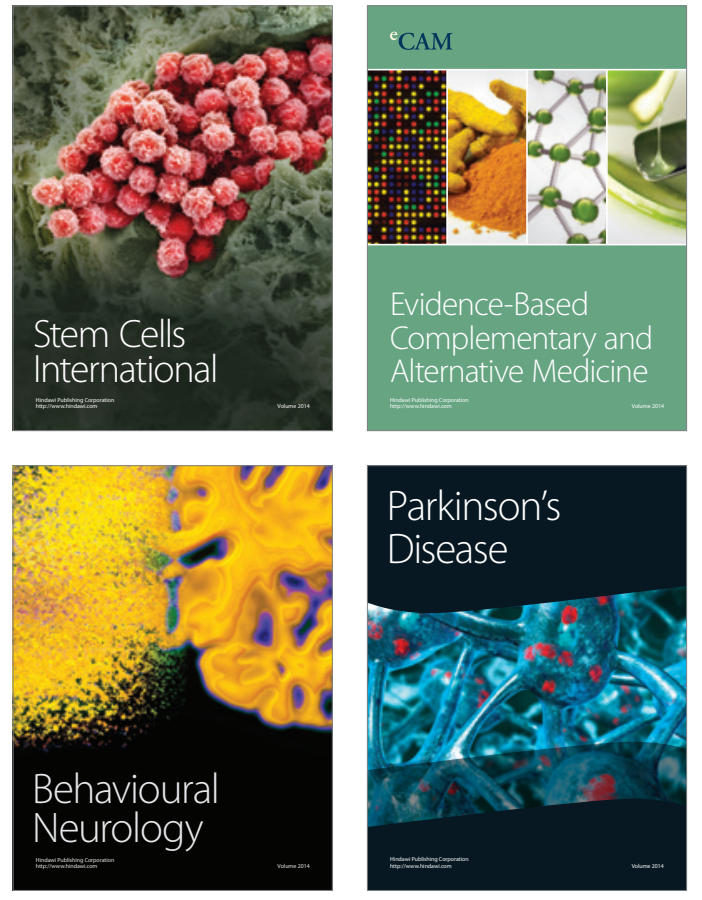
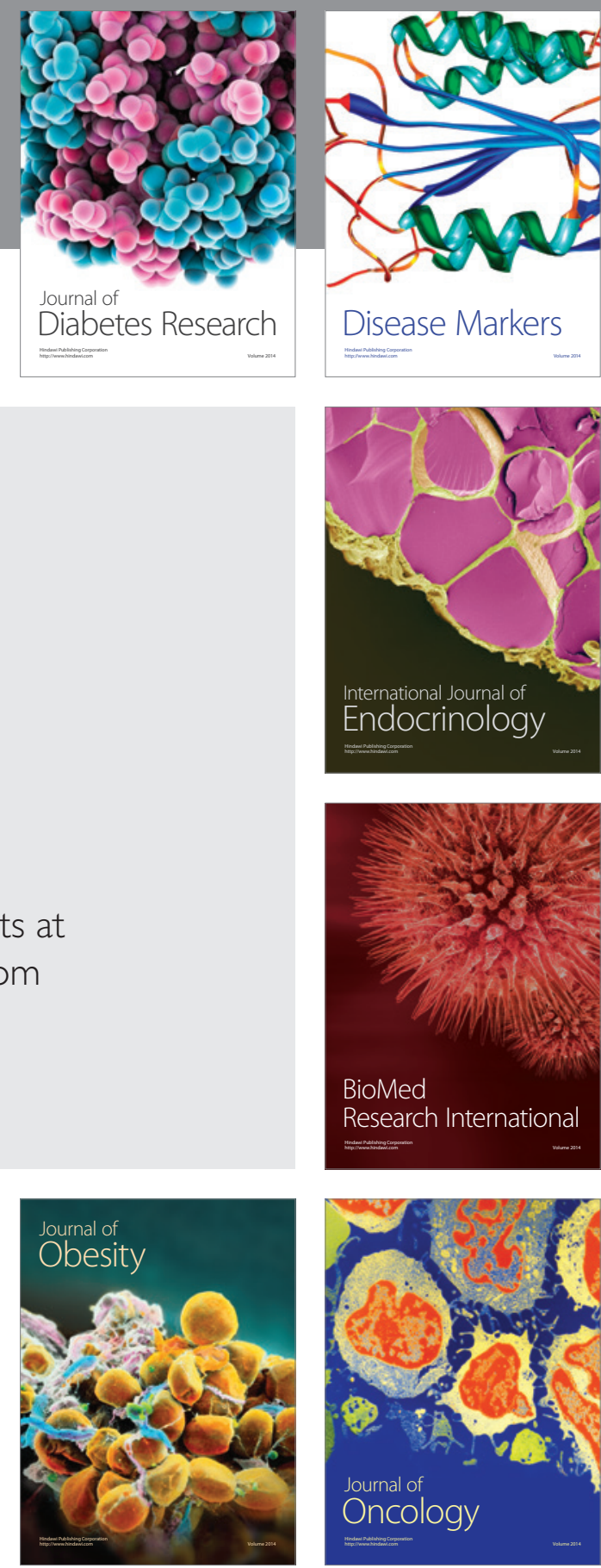

Disease Markers
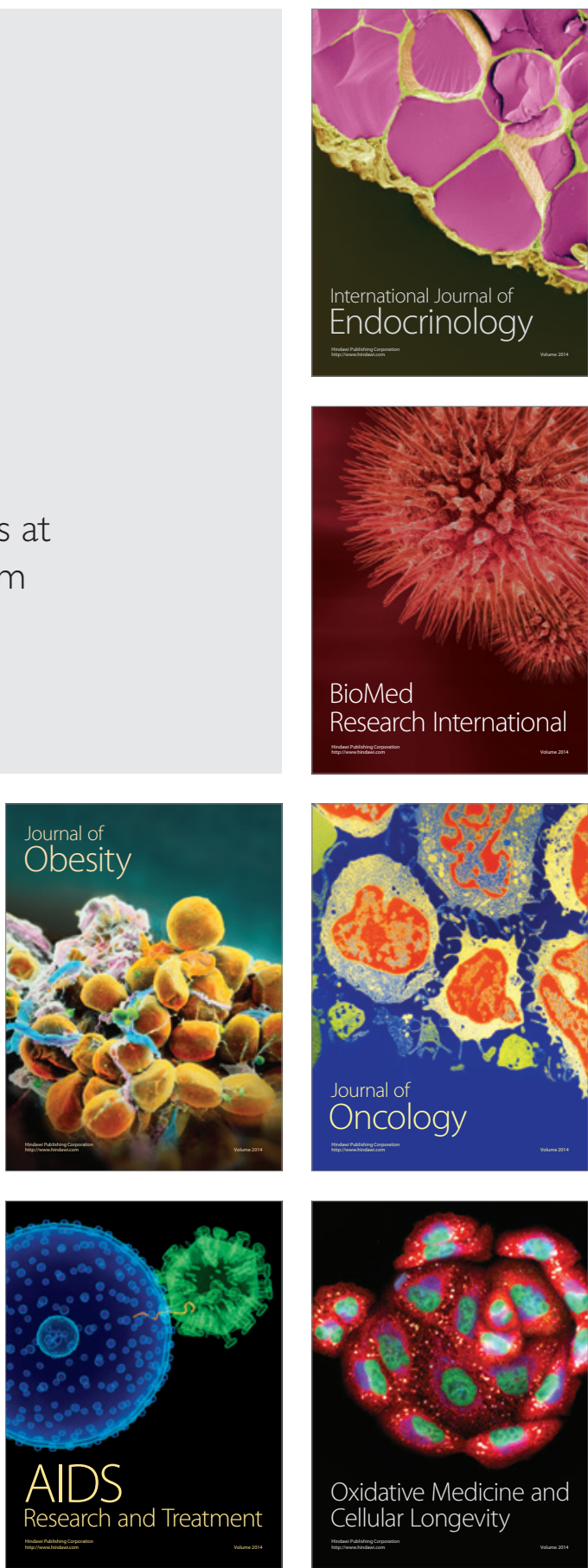